\title{
PUTTING OXFAM'S PARTNERSHIP PRINCIPLES INTO PRACTICE
}

Oxfam's Partnership Toolkit: Minimum requirements and good practice guidelines

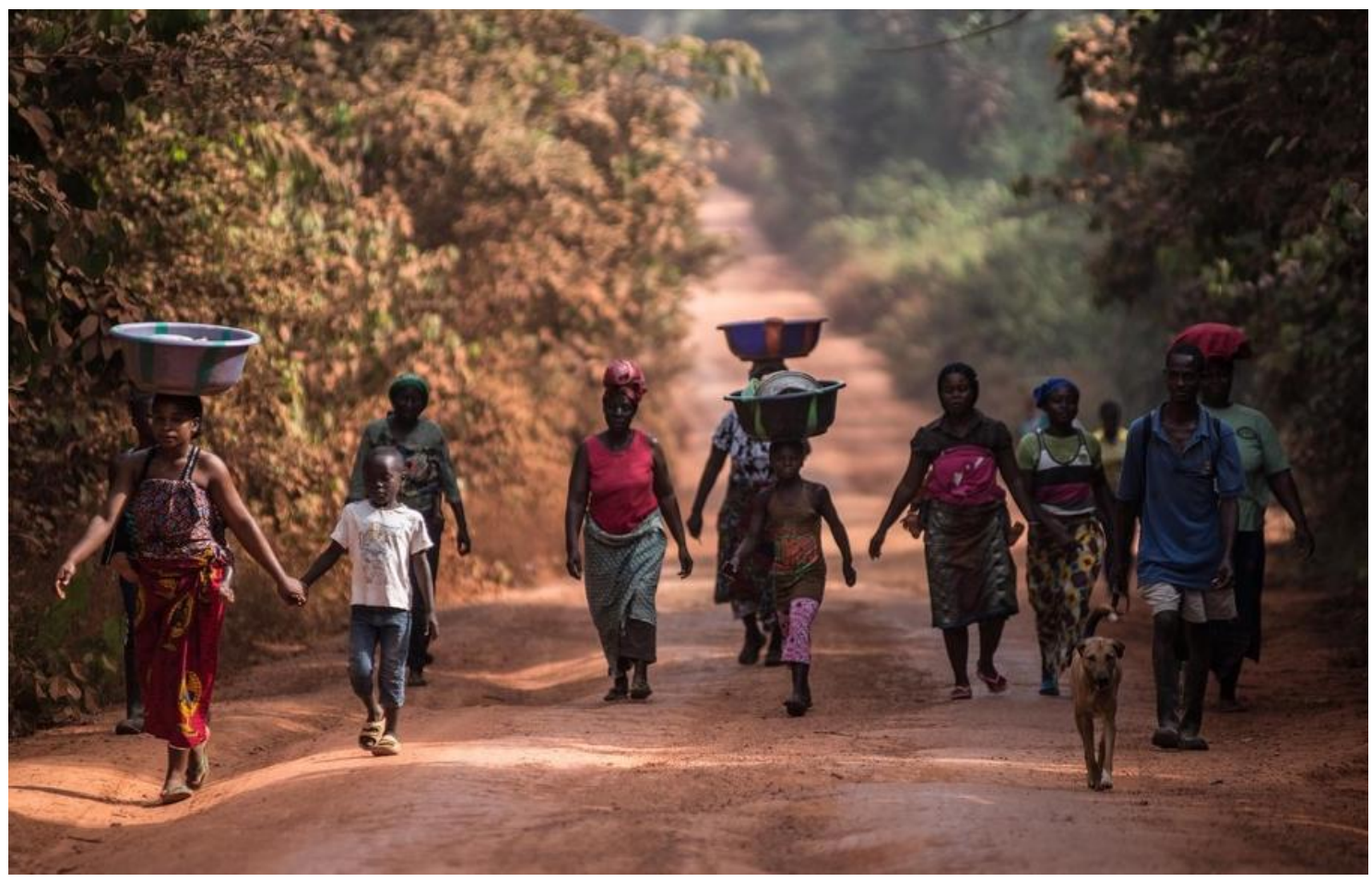

Oxfam is working with communities in Tappita district, Liberia, to help families get back on their feet after the Ebola crisis (2015). Photo: Tommy Trenchard/Oxfam 


\section{WHY DO I NEED TO REFER TO THE OXFAM PARTNERSHIP TOOLKIT?}

This document will help you to put Oxfam's Partnership Principles into practice. It contains procedures we need you to follow to ensure that Oxfam is setting up the best partnerships possible. This document contains refinements to the procedures you are already using particularly around Oxfam's and partners' shared responsibility for accountability to primary and key stakeholders - prompted by recent feedback and learning offered by staff and partners.

Oxfam works with others to take action to achieve common goals for overcoming poverty and injustice. Our aim is to achieve consistently good quality and honest relationships with all of our partners. This will be achieved through paying attention to ways of working, as well as maximizing impact by delivering good financial and programme management.

Relations with Oxfam's partners are based on mutual respect for the contribution that each party brings. And they are informed by - and managed to - the following set of clear principles which underpin our programme and partnership decisions in development, humanitarian, and campaigns work at every level of activity:

- Shared vision and values

- Complementarity of purpose and value-added

- Autonomy and independence

- Transparency and mutual accountability

- Clarity on roles and responsibilities

- Commitment to joint learning.

We hold ourselves accountable to these principles and seek to be held accountable by partners, communities, and other stakeholders with whom we (and our partners) work.

Many regional and country teams have developed their own tools and guidelines - and we hope that you will continue to use these, if they are working for you.

But please ensure that your present tools incorporate the minimum requirements that are set out in the following sections; they are essential for ensuring responsible sign-off by your Country Director on any new or renewed agreement to partner with another group or organization.

In Oxfam's Partnership Toolkit you will find the following procedural requirements:

\section{- Section 1 - Should we work together?}

Guidelines on how to assess the potential value and strategic fit of a partnership.

\section{- Section 2 - Assessing capacity for delivery of specific projects}

It's essential to evaluate the capacity of Oxfam and a prospective partner to carry out a joint piece of work. Refer to the revised guidelines in this section.

\section{- Section 3 - Good partnership conversation}

Guidelines to help ensure that Oxfam and its partner(s)discuss how they want their partnership to work - and how Oxfam's six principles of partnership will be put into practice.

\section{- Section 4 - Letter of Agreement}

The formal contract between Oxfam and its partner for any project or initiative - and everything that it needs to contain. 


\section{Important for Oxfam staff: All of the procedures discussed in the sections above are mandatory; you must document them and attach them to OPAL. 1}

\section{- Section 5-Good practice guidelines}

Full of ideas, procedures, experiences, and successes that we have gained from consultation with staff and partners. With your input, we will continue to add to this section in the years to come, to enable optimum work with partners.

New elements introduced in this toolkit are intended to place a stronger focus on the mutual accountability between Oxfam and its partners and the shared accountability that Oxfam and its partners have to primary and key stakeholders. This toolkit is basically series of essential questions that you should ask to assess the capacity of Oxfam and the partner to work together to achieve effective results.

These questions are not an exhaustive list - your local knowledge (and other local/specific contexts) may mean that some may not even be relevant. And you may need to consider other issues around risk, security, political context, or human resource issues.

Increasingly, Oxfam is working with others in partnerships that are not grant-based. It is recommended that these same procedures be adapted and used as the basis for non-grant working relations with others: NGOs, the private sector, government or other bodies.

Oxfam expects all programme staff to use their judgement in establishing honest and effective partnerships and to be clear about:

- what the judgement is based on;

- how opportunity and innovation will be maximized;

- how risk will be managed; and

- how mutual accountability can be achieved.

\section{IF YOU NEED FURTHER HELP AND SUPPORT}

Please contact your regional Programme Quality and MEAL lead in the first instance. Also feel free to contact Yo Winder (ywinder@oxfam.org.uk) or Jan Bouwman

(jbouwman@oxfam.org.uk)who will be happy to try to support you in any work on partnership.

We will be developing further support materials and capacity building over the next year, and will continue to consult with and build on ideas from staff and partners.

Please feel free to visit the Partnership page on Oxfam's Policy and Practice web site for further information and learning around how to be the best partner we can be. The latest and widest collection of learning, tools and guidance on partnership are available there (still being gathered from across the Oxfam confederation and beyond).

June 2016

1 OPAL is an Oxfam GB internal project management and information system (Oxfam Project, Accountability and Learning). 


\section{SHOULD WE WORK TOGETHER? ASSESSING THE STRATEGIC FIT}

\section{Purpose}

To assess the potential value of a partnership with another organization and the strategic fit with Oxfam's programme strategy. This is a required minimum standard for establishing a partnership.

An assessment of the strategic fit will take place when you are first considering whether Oxfam and another entity or community should work together. It enables an overview assessment of both Oxfam and the partner to take forward a partnership that may involve separate grants over time for different pieces of work. You only need to revise this assessment if the partner's or Oxfam's context changes significantly - leading to a reassessment of the overall partnership. It does not need to be revised for every specific project grant.

This assessment is not designed to assess the capacity of a partner to do a specific piece of work for which a grant will be made. That is covered in section 2: Assessing capacity for specific project delivery.

Sign off: By the Project Manager (named in OPAL) and attached to OPAL.

\begin{tabular}{|c|c|c|c|}
\hline \multicolumn{4}{|l|}{ Partner name: } \\
\hline \multicolumn{4}{|l|}{ Partner address: } \\
\hline \multicolumn{4}{|l|}{ Name of Director: } \\
\hline \multicolumn{4}{|l|}{ Date founded: } \\
\hline \multicolumn{4}{|l|}{ Date of assessment: } \\
\hline \multicolumn{4}{|l|}{$\begin{array}{l}\text { Carried out by Oxfam Project Officer or } \\
\text { Programme Manager: }\end{array}$} \\
\hline Overall assessment of strategic fit: & Suitable & $\begin{array}{l}\text { Needs } \\
\text { further } \\
\text { work }\end{array}$ & $\begin{array}{l}\text { Not } \\
\text { suitable }\end{array}$ \\
\hline Assessment approved: & Name: & & Date: \\
\hline \multicolumn{4}{|l|}{ Next steps (what, who, when etc): } \\
\hline
\end{tabular}


Parts 1 and 2 below contain a series of questions. You may need to ask follow-up questions. This list is intended to help guide the discussion and to allow you to answer the question in the box in each section. ${ }^{2}$ It is your judgement, based on answers to the questions, which matters in establishing the partnership. Please record in the comment box the principal factors in reaching your decision.

This is also an important opportunity for you to offer information about Oxfam's objectives, as well as to explain to potential partners why you are asking these questions.

\section{PART 1: OXFAM}

\section{Oxfam's contribution to the partnership}

- Does Oxfam have a history of working with partners in this country/geographical area? If not, what should Oxfam be doing to ensure understanding of the context?

- Does Oxfam have a history of working on themes/issues similar to the partner? If not, what should Oxfam be doing to ensure sufficient knowledge/understanding?

- How do Oxfam's culture and values fit with those of the partner?

- Is Oxfam the best source of expertise, money, or contacts for the partner?

\section{Is Oxfam the most appropriate partner?}

\begin{tabular}{|l|l|l|}
\hline Yes & No & Comments \\
\hline & & \\
\hline
\end{tabular}

\section{Oxfam's capacity to deliver}

- Does Oxfam have the skills and experience to support this partner? If not, how will Oxfam ensure that the partner receives the support necessary?

- Does Oxfam have skills and experience to manage this type of partner relationship?

- What should Oxfam do to make the relationship work? Does this require any:

- specific capacity building within Oxfam?

- broader changes in ways of working within Oxfam?

- capacity building work with the partner?

- If so, what and why? Is this reflected in the OPAL project plan and budget? ${ }^{3}$

\section{Does Oxfam have the capacity to deliver its part of the partner relation?}

\begin{tabular}{|l|l|l|}
\hline Yes & No & Comments \\
\hline & & \\
\hline
\end{tabular}

2 Not all questions will apply to all organizations: in some countries, very few organizations will have an HIV/AIDS policy. This tool enables you to take a range of concerns into account in forming your judgement about whether to establish a partnership.

3 OPAL (Oxfam Programme Accountability and Learning) is Oxfam's internal programme management and information system. 


\section{Oxfam's accountability}

- Is the partner aware of Oxfam's partnership policy? How will the partner hold Oxfam accountable for the partnership principles?

- How will Oxfam enable the partner to have an overview of its work in the country/area, so that the partner can assess strategic fit for themselves?

- What accountability mechanisms will Oxfam put in place to ensure that it delivers on its promises to this partner?

- How will the partner learn about the different types of support that Oxfam can provide?

- Are informal systems in place to resolve issues as they arise?

- Is the partner aware of Oxfam's complaints mechanism? Are Oxfam staff clear on how the complaints mechanism operates?

- Is the partner aware of Oxfam's policy on sexual abuse and exploitation? Are Oxfam staff clear on how this policy operates?

- Has a discussion taken place on how to carry out accountability responsibilities to people living in poverty and other key stakeholders? What are Oxfam's roles and responsibilities in this regard?

Are appropriate systems in place to ensure that Oxfam will be accountable to this partner?

\begin{tabular}{|l|l|l|}
\hline Yes & No & Comments \\
\hline & & \\
\hline
\end{tabular}




\section{PART 2: THE PARTNER ORGANIZATION}

\section{Strategic fit}

- What are the partner organization's purpose and mission?

- What are the partner organization's values?

- What kinds of programmes/projects does the partner undertake?

- How does the partner's approach relate to long-term development, humanitarian response, and/or campaigning and advocacy?

- What are the partner organization's links and alliances with other organizations?

- What is the partner organization's position on gender issues, HIV and AIDS, sexual abuse and exploitation? What, if any, are its policies on these issues? Is the partner in broad agreement with Oxfam's policies and willing to work with these policies?

- What is the organization's governance structure? Does this allow for a distinction between duties? Does it address issues around conflicts of interest?

Does the organization have a clear vision, purpose, principles and governance? Are these compatible with Oxfam's mandate, principles and ways of working?

\begin{tabular}{|l|l|l|}
\hline Yes & No & Comments \\
\hline & & \\
\hline
\end{tabular}

\section{Involvement of people and communities living in poverty}

- In what ways are the partner organization accountable to and/or representative of the people and communities with whom it works?

- Is the partner committed meeting Oxfam's accountability minimum standards?

- How are minorities, the disenfranchised, or the poorest involved?

- What is the partner organization's understanding of, and response to, gender and diversity issues and gender relationships of the people and communities with whom it works?

- What is the partner organization's understanding of, and response to, HIV and AIDS issues of the people and communities with whom it works?

- How does the partner handle issues of sexual abuse and exploitation?

Is the nature of the relationship with people and communities and their ways of involvement satisfactory?

\begin{tabular}{|l|l|l|}
\hline Yes & No & Comments \\
\hline & & \\
\hline
\end{tabular}

\section{Management, finance and systems}

- Is the organization compliant with national statutory and legal requirements?

- How is the partner organization managed?

- How effective and efficient are the partner organization's administrative systems and controls? Do they have financial policies and authorisation procedures?

- How strong is the partner organization's financial management? Will it enable it to meet basic accounting standards and manage resources for programme delivery? 
- What assets and liabilities are there?

- What is its record on donor reporting? How does it monitor/record donor funds?

- What is the funding base? Is it able to mobilize new resources when required or is it dependent on one source?

- What is the skills base of the organization?

Is the type and quality of management appropriate for the size and type of organization?

\begin{tabular}{|l|l|l|}
\hline Yes & No & Comments \\
\hline & & \\
\hline
\end{tabular}

\section{Engagement with others}

- Who are the organization's main stakeholders?

- How will the organization meet Oxfam's accountability minimum standards in its relationships with key stakeholders?

- How does the organization strive to maintain its independence?

- With whom does the organization have strong relationships?

- Does the organization make any sub grants? If so, to whom and how are they managed?

\section{Do any of the organization's relationships present a risk to Oxfam?}

\begin{tabular}{|l|l|l|}
\hline Yes & No & Comments \\
\hline & & \\
\hline
\end{tabular}

\section{Known achievements and challenges}

- What are the partner organization's recent achievements?

- What is the partner organization's record of achieving project or programme objectives?

- How has the organization engaged with influencing policy change? With what impact?

- What is the organization's experience of responding quickly and appropriately to emergencies?

- What challenges does the organization face?

On the basis of its record to date, is it likely that the partner organization will achieve the results that it sets out to achieve?

\begin{tabular}{|l|l|l|}
\hline Yes & No & Comments \\
\hline & & \\
\hline
\end{tabular}




\section{ASSESSING CAPACITY FOR SPECIFIC PROJECT DELIVERY: PARTNER ORGANIZATION AND OXFAM}

\section{Purpose}

To assess the capacity of Oxfam and the partner to manage/implement a specific project or initiative. This is a required minimum standard and is the basis for preparing the Funding Agreement. This assessment must be completed for every specific project grant to a partner organization.

Sign off: By the Project Manager (named in OPAL) and attached to OPAL.

\begin{tabular}{|c|c|c|c|}
\hline \multicolumn{4}{|l|}{ Partner name: } \\
\hline \multicolumn{4}{|l|}{ Project title: } \\
\hline \multicolumn{4}{|l|}{ Project ID if known: } \\
\hline \multicolumn{4}{|l|}{ Programme (PIP) ID if known: } \\
\hline \multicolumn{4}{|l|}{$\begin{array}{l}\text { Assessment done by: [name of } \\
\text { Oxfam staff person] }\end{array}$} \\
\hline \multicolumn{4}{|l|}{ Date of assessment: } \\
\hline $\begin{array}{l}\text { Overall assessment of } \\
\text { partner's capacity to deliver: }\end{array}$ & Suitable & $\begin{array}{l}\text { Needs further } \\
\text { work }\end{array}$ & $\begin{array}{l}\text { Not } \\
\text { suitable }\end{array}$ \\
\hline $\begin{array}{l}\text { Overall assessment of Oxfam's } \\
\text { capacity to deliver: }\end{array}$ & Suitable & $\begin{array}{l}\text { Needs further } \\
\text { work }\end{array}$ & $\begin{array}{l}\text { Not } \\
\text { suitable }\end{array}$ \\
\hline Assessment approved: & Name: & Date: & \\
\hline \multicolumn{4}{|l|}{$\begin{array}{l}\text { Next steps: [what, who, when, } \\
\text { etc.] }\end{array}$} \\
\hline $\begin{array}{l}\text { Refer to comments on partner } \\
\text { and Oxfam capacity. }\end{array}$ & & & \\
\hline
\end{tabular}

Under Parts 1 and 2 below, you will find a series of questions. You may need to ask follow-up and/or different questions. This list is intended to help guide the discussion and to allow you to assess the partner's and Oxfam's capacity to do a specific piece of work, i.e. a project or part of a project. It is your judgement based on answers to the questions that matters in deciding whether to proceed to make a grant or support the project.

Any capacity building needs of Oxfam or the partner organization should be clearly outlined, including how these will be met. 


\section{PART 1: OXFAM}

- Has Oxfam worked with this or another similar partner organization successfully before?

- What support and capacity building is needed from Oxfam or from other sources to help the partner organization achieve its objectives?

- Does Oxfam have the capacity - directly or indirectly (i.e. through others) - to provide support and capacity building to help the partner organization achieve its objectives?

- What capacity building needs do Oxfam staff have to provide appropriate support to the partner?

- How have capacity building needs - of both the partner and Oxfam - been included in thinking through the staff time and financial resources allocated to this project?

- What mechanism is in place for the partner to hold Oxfam to account for these and other commitments, e.g. paying grants on time, providing feedback on project reports?

- Has Oxfam discussed and agreed with the partner how Oxfam's accountability minimum standards will be met?

- Are informal systems in place to resolve issues as they arise?

- Given the cost of support, is working with this partner organization a cost-effective way of achieving our project and programme aims?

- Is Oxfam clear on its role and responsibilities as part of the exit strategy for the project?

- How will any wider organizational learning that Oxfam can contribute to this specific project and/or partner be made available and/or applied?

\section{Comments on assessment of Oxfam}

\section{General}

Specific capacity building needs of Oxfam staff: What are they and how will they be met? 


\section{PART 2: THE PARTNER ORGANIZATION}

- What are the outcomes and specific activities of the specific project under consideration?

- What are the organizational and individual skills and capacities (including managerial, technical, and financial) needed to achieve project outcomes and/or activities? Does the organization have these skills? If not, how will they be acquired?

- What management and control systems are in place (e.g. authorization procedures, cash and bank management)? Are they adequate for the project involved? If not, what steps will be taken?

- Is the partner meeting or able to meet the relevant government's statutory and other legal requirements (accounts, audit, annual reports, etc.)?

- What are the skills and capacity needed to meet donor requirements (including reporting), and does the project have these?

- Does the partner agree with and have the capacity to meet Oxfam's accountability minimum standards?

- Does the partner have access to, and credibility with, either people and communities living in poverty and/or with those whom the partner is seeking to influence?

- How will the partner and Oxfam share the responsibility for accountability to primary and key stakeholders of the project?

- Has the partner organization completed similar projects successfully before? If this is an innovative or new departure for the partner, how is the organization going to carry it forward?

- What learning has the partner organization taken and applied from previous projects?

- What kind of track record does the partner have in:

- assessing and managing risk?

- completing projects to budget and on time?

- providing accurate narrative and financial reports on time?

- How has an exit strategy been considered to ensure the sustainability of project outcomes?

\section{Comments on partner assessment}

\section{General}

Specific capacity-building needs: What are they, and how will they be met? 


\section{GOOD PARTNERSHIP CONVERSATION (GPC)}

\section{Purpose}

To introduce the good partnership conversation. The main aim of the GPC is to ensure that Oxfam and partners have an open dialogue about how they would like the partnership to work in terms of attitudes and behaviours as well as practicalities and compliance. This is a crucial process in ensuring that, as Oxfam, we are committed to putting the six principles of the Partnership Policy into practice.

The good partnership conversation is a required minimum standard when establishing a partnership for a specific project or initiative with communities and other organizations, including NGOs, government, and the private sector.

It is important that the GPC is held as near to the beginning of the partnership as possible ideally after the formal appraisal process; although it is likely that some of these issues may surface during the appraisal process. The GPC needs to take place before any contract is signed. A note reflecting the conversation should form part of the funding Letter of Agreement.

\section{Why do we need a GPC?}

Oxfam's Partnership Principles present our vision of partnership. They describe principles we think are important and for which we want to be held accountable.

Other minimum requirements focus more on compliance issues, e.g. what both sides of a partnership must do by virtue of their legal, institutional or charitable status, and to ensure effective resource management. These are outlined in the Letter of Agreement or contract, and it is essential that staff and partners comply with the terms of the funding agreement. But to achieve the kinds of partnerships to which we aspire, we need to ensure effective ongoing dialogue with partners to build trust and openness - starting with an initial conversation about how, together, we will put the partnership principles into practice with a periodical review about how our partnership is working.

A good partnership conversation is simply a way of creating space and time to discuss these responsibilities and agreements so that we can agree and revisit them together and remind each other of them. When staff and partners have a clear understanding of what the partnership is for and the expectations of how to behave within it, staff will feel empowered to act with confidence that what they are doing is appropriate. By being open with each other about these expectations and about when we feel they are not being met, we develop relationships based on trust and accountability.

\section{What areas could a GPC cover?}

The objective of the GPC is a dialogue between Oxfam and partners, and the common understanding this leads to about how Oxfam and partners will put the partnership principles into practice. While it may well cover more procedural aspects of how we will work together, the main aim is to focus on the attitudes and behaviours which all parties feel are essential to ensure effective, open and accountable partner relations.

The conclusions of the conversation should be captured either as part of the funding agreement 'contract' or in a separate note agreed by Oxfam and the partner(s). This will enable all parties to hold each other to account. 
The GPC should enable people to discuss, in relation to each of the principles of the Policy:

- What we need to know and understand about each other and how we will get that awareness.

- The attitudes and behaviours we expect and how we will help each other to practise these.

- The processes and procedures we will put in place to hold each other accountable for practising the principles and increasing trust in the partnership.

- The responsibilities and accountabilities we have and how these will be met, and what will happen if they are not met.

\section{How should a GPC be run?}

There is no standard methodology for this, but the process could include:

- sharing the Partnership Policy with a broad cross-section of Oxfam and partner staff;

- a discussion between Oxfam and partner managers to agree how and when the conversation will be held and how it will be run;

- separate processes of reflection and discussion by Oxfam and partner staff respectively, talking through each of the principles of the Policy and what they could look like in practice;

- a meeting of staff from both parties to present their ideas on how they will put the policy into practice

Once the outcomes are documented (in whatever way makes most sense for the partnership), these should then be circulated to partner and Oxfam staff, and attached as part of the partnership documentation on OPAL. 


\section{MINIMUM REQUIREMENT 4}

\section{LETTER OF AGREEMENT TEMPLATE}

Letter of Agreement between Oxfam GB and specific project implementation

[organization name] for

Summary

Project title:

Project ID:

Project start date:

Project end date:

\section{CRIMSON ID}

(if relevant and to be updated as partner receives additional funding sources):

Project manager:

Partner name:

Amount in GBP:

Amount in local currency (stating source/date of exchange rate to be used): 


\section{Introduction}

Oxfam GB aspires to build partnerships that are inclusive, accountable, empowering, and based on relationships of openness and trust. Oxfam GB's Partner Relations will be informed by and managed to a set of clear principles. These five principles are outlined in Oxfam GB's Partnership Policy (Annex 1) and underpin its programme and partnership decisions in development, humanitarian, and campaigns work at every level of activity.

\section{[Region/country to attach a copy of the Partnership Principles to each funding agreement letter as Annex 1]}

This funding agreement is entered into by [organization name] and Oxfam GB. The process leading up to signing this agreement should have included discussions taking into account how the partnership will work and an assessment of the capacity of both Oxfam GB and the partner organization to deliver project objectives and activities.

This will have also included agreement about what non-financial support Oxfam GB will bring to the partnership, e.g. for capacity building and other aspects of institutional support. Oxfam GB and ___ [organization name] should also have a shared understanding about all project deliverables; Oxfam GB's and 's [organization name] roles and responsibilities in achieving the project outcomes and a clear understanding of the exit strategy when the project ends.

\section{Objectives}

\section{[Region/country to fill in]}

Describe what Oxfam GB and [organization] want to achieve together.

\section{Specific use to which designated funds from Oxfam GB are to be put}

Oxfam GB has approved a grant of [£ sterling]

OR

Oxfam GB has approved a grant of $£$ sterling. [local currency]. At date of signing, this represents

The grant is made in relation to Project [include project title and ID] based on a project proposal agreed between [organization name] and Oxfam GB. The grant must be used exclusively by [organization name] for the agreed Project and in accordance with the attached project proposal and budget (Annex 2 ) which form an integral part of this agreement. The financing for this grant is provided by [specify source of restricted or unrestricted funding].

The objectives, milestones and outputs of the project are outlined as follows. Achievement of these milestones and outputs according to the attached project and budget represent the conditions against which Oxfam GB will agree to pay remaining instalments of the project budget. Where project activities are funded by an external donor, milestones and outputs will correspond to those outlined in Oxfam GB's agreement with the donor.

\begin{tabular}{|l|l|l|}
\hline Objectives & $\begin{array}{l}\text { Project milestones/outputs } \\
\text { against objective }\end{array}$ & $\begin{array}{l}\text { Date for achievement of } \\
\text { milestones }\end{array}$ \\
\hline Year 1 & & \\
\hline Year 2 & & \\
\hline Year 3 & & \\
\hline
\end{tabular}


Any proposed changes to the project objectives, implementation and/or any consequent budget changes must be formally agreed in writing between [organization] and Oxfam GB and

attached as a dated Appendix to this agreement.

\section{Oxfam GB's responsibilities}

\section{[For region/country to fill in]}

Please include a paragraph which states clearly how Oxfam GB will support the partner organization, what the partner can expect, who in Oxfam GB is responsible for delivery and by when. This could include capacity building on technical and professional skills, finance and administration, organizational development, meeting donor reporting requirements, etc. Some of these issues will have been covered in the GPC. This section should enable the partner organization to hold Oxfam GB accountable. Annex 3 includes an example of how this might look.

Disbursement schedule: [The disbursement schedule should also be included here.]

The grant will be disbursed as per the following timetable, and on receipt of appropriate reports from the partner organization:

- Tranche 1: xxx currency payable on $x x x$ date

- Tranche 2: $x x x$ currency payable on $x x x$ date

- Tranche 3: xxx currency payable on xxx date

Code of Conduct: Oxfam GB expects all of its staff members to follow Oxfam GB's code of conduct, which is attached as Annex 4. [Region/country to attach] If [organization] feels that any part of Oxfam GB's Code of Conduct is not being followed, they should raise this immediately with [name of Country Programme Manager]. If this does not resolve the issue, then they should discuss the issue with the Regional Programme Manager [insert name of RPM] or the Regional Director [insert name of Regional Director].

\section{4 's [organization name] responsibilities}

\section{[For Region/country to fill in]}

Please include a paragraph which states clearly what the partner organization is responsible for, including stating how grant money will be spent and how this will achieve project objectives. This paragraph will build on the specific milestones and outputs outlined in section 2 . Annex 3 includes an example of how this might look.

\section{Requirement of a report from the partner on the use of grant funds}

[organization name] must keep financial records of the project in line with the project description, according to standard accounting practices, and must meet the (relevant) government's statutory and legal requirements for accounts, audit, annual reports and annual returns.

Oxfam GB requires progress reports every months and financial statement of income and expenditure according to the budget heads agreed every months. The reports should outline how programme/project objectives are being/have been achieved and financial reports should be signed by an authorised officer (e.g. Treasurer or authorized accountant).

\section{Report due dates:}

- Six-month: xxxx (financial and narrative)

- Year 1: xxxxx (financial and narrative)

- Etc. 
An independently audited annual statement of accounts is to be given to Oxfam GB unless otherwise stated.

\section{Oxfam GB's right to check on the use and the expenditure of the funds}

Oxfam GB reserves the right to monitor and evaluate activities implemented by the partner. In order to do this, Oxfam GB's authorized representatives will from time to time visit the project, normally at times agreed in advance, to see the progress of the project and review financial records and accounts. Oxfam GB reserves the right to visit without prior notice.

Oxfam GB reserves the right to examine all financial records and materials purchased with Oxfam GB funds, and to audit use of funds with reference to the budget proposal.

[organization name] agrees to return to Oxfam GB any funds not used for the agreed project. If the agreed project objectives and conditions are not met, Oxfam GB may reclaim the disbursed funds, either wholly or in part.

\section{Oxfam GB's right to terminate or suspend the grant}

Failure to comply with the terms of this agreement may result in immediate cessation of funding and/or support from Oxfam GB. Oxfam GB has the right to terminate the grant early and to stop all payments if:

- _ [organization name] fails to comply with any of the terms of this agreement, including use of funds outside of this agreement or fraudulent use of funds; or

- Oxfam GB is required by local or central government or court to suspend or terminate the grant; or

- geographical, security or other conditions prevent the partner from using the grant in accordance with the project proposal, or Oxfam GB from carrying out the checks in this agreement, or

- _ _ [organization name] no longer carries on activities of the kind in the project proposal or loses its approval from the administrative authorities for this kind of activity, or

- this grant is funded by GB to suspend or terminate the grant.

In the case of a multi-year grant (i.e. grant disbursements over more than one Oxfam GB financial year), Oxfam GB reserves the right to cancel or postpone disbursements if the partner cannot demonstrate that the objectives for the first year or subsequent years have been achieved.

\section{Quality and sector specific standards and requirements}

In addition to this agreement, the following quality and/or sector requirements apply, for which Oxfam GB will provide support to the partner.

[Region/country to adapt/delete as required] Add sector specific requirements as appropriate, e.g. Sphere Standards

\section{Procurement}

If the budget permits [organization name] to buy goods or services, then [organization name] shall ensure there is a procurement process in place, which demonstrates probity and value for money. If [organization name] does not have a procurement process in place, then it will be expected to follow Oxfam GB's procurement requirements. If the project is financed by another donor, [organization name] agrees to comply with the donor's procurement requirements. 
[Region/country to attach Oxfam GB's or donors procurement requirements as appropriate]

\section{The activities are legal}

[country name].

[organization name] agrees to comply with all applicable laws in

\section{Violence and money laundering}

[organization name] agrees to ensure that to the best of its knowledge and belief, it

will not promote or engage in violence, terrorism, or money laundering, nor will it make subgrants to any entity that engages in these activities. Any sub-grants by [organization name] will include an equivalent obligation.

\section{Meeting additional donor requirements}

[Region/country adapt/delete as appropriate]

This project is funded by [donor name]. As a consequence, [organization name] agrees to work with Oxfam GB to ensure that the project complies with the following additional donor requirements for this project, included as Annex 3

[Region/country to outline any additional donor requirements as Annex 5]

\section{Communication, resolution of problems, and Oxfam GB Complaints Policy}

Both Oxfam GB and [organization] agree to communicate openly, transparently and constructively and to try to resolve any issues locally. If [organization] feels that communication is not open, transparent, or constructive or feels that it cannot resolve an issue locally, the organization may use Oxfam GB's Complaints Policy. The Complaints Policy has been established by Oxfam GB to ensure that a transparent and effective mechanism is available to all those affected by Oxfam GB's work to register significant concerns about Oxfam's work. All Oxfam GB staff are committed to ensuring that the Complaints Policy is widely communicated and managed effectively. The Complaints Policy is attached as Annex 6.

[Region/country to attach with local contact information and guidance re: use of policy locally.]

If ___ [organization name] prefers, it could also raise the issue with a third-party organization to help find a resolution. Such an organization might be a national NGO platform or any third-party organization agreed by Oxfam GB and [organization name].

\begin{tabular}{|l|l|}
\hline \multicolumn{1}{l|}{ Oxfam GB } & \multicolumn{1}{c|}{ [organization name] } \\
Signature: & Signature: \\
Name: & Name: \\
Job title: & Job title: \\
Date: & Date: \\
\hline
\end{tabular}




\title{
ANNEX 1
}

Oxfam GB Partnership Policy

\section{ANNEX 2}

Project proposal and budget

\section{ANNEX 3}

This is an example of an outline of partner and Oxfam GB main responsibilities, which could also represent a summary of the good partnership conversation.

\section{Partner main responsibilities}

- To carry out the field-level implementation of the project in accordance with the detailed approved budget and planned activities included in the agreement.

- To have the needed technical, management and social promotion personnel to fulfil the objectives of the project.

- To execute, direct, monitor and follow up the technical, organizational and training activities to ensure the achievement of the project targets.

- To submit a narrative and financial report every $x x x$ months, following the specific Oxfam GB guidelines and accounting/banking requirements detailed in the agreement. (Specific dates for report submission are included in the funding agreement.)

- To carry out participative evaluations every three months to identify the needed implementation changes that should be pursued to fulfil the objectives and targets of the project.

\section{Oxfam GB's main responsibilities}

- To accompany the field implementation process, establishing effective communications, good co-ordination and effective working relationships with $\mathrm{xxx}$ [organization] staff.

- To identify with $x x x$ [organization] the learning and evaluation requirements, advice and qualified technical support needed to ensure that project objectives and activities are met. Capacity building needs should be outlined and agreed separately with xxxx [organization].

- To provide comments to narrative and financial reports not later than $x x x x$ days after submission of the reports.

- To monitor the budget execution, in order to verify its correct management according to the detailed budget included in the agreement. If Oxfam GB needs to audit the project, [the partner] will commit to provide the required assistance.

- To make finance payments on time, as per schedule included in funding agreement (assuming partner responsibilities have been met).

- To participate in the processes of systematic evaluation and the final evaluation of the project.

\section{ANNEX 4}

Oxfam GB Code of Conduct

\section{ANNEX 5}

Additional donor requirements

\author{
ANNEX 6 \\ Oxfam GB Complaints Policy
}




\section{GUIDELINES AND IDEAS FOR GOOD PRACTICE IN PARTNERSHIPS}

\section{Purpose}

To offer guidelines and practical ideas to help staff develop skills and to promote attitudes, behaviours, and procedures that will lead to effective partnerships and make a reality of Oxfam's six partnership principles.

These ideas and guidelines have been drawn from consultation with staff and partners during the development of the Partnership Principles and through several evaluations of how Oxfam works in partnership.

\section{Partner welcome pack}

Some countries are considering the idea of a partner welcome pack. Feedback from partners highlighted their strong interest in learning more about Oxfam: its strategy in-country; what other kinds of work it is supporting and where Oxfam is working; and simple things such as 'Who I can talk to if the usual contact person isn't around?'. A small effort putting together a pack with some basic information about Oxfam's work in the country, its overall programme portfolio; names and contact information for staff; staff structure (so the partner can see where the person they know fits in) along with for example, the Partnership Policy, Gender Policy, humanitarian response approach, advocacy and campaigning ... in short, anything that would help partners understand more about Oxfam. This will enable them to have a better sense of what their specific initiative links to in terms of the overall Oxfam country programme.

\section{Time with partners}

Partners like visits by the Project Officer and by other staff. Face-to-face contact encourages trust and openness and enables partners to solve problems innovatively, as they arise. Time spent building relationships and understanding between Oxfam and its partners is critical to mutual accountability. Partners emphasise the value of face-to-face reflection, review and dialogue. Joint field visits from programme and finance staff are useful for supporting partners with financial reporting and for mentoring.

\section{Advocacy support}

Oxfam is committed to developing the ability of its partners to undertake campaigns and advocacy; it seeks to take a leading role only where this is mutually agreed to be of strategic advantage. Oxfam wants to link different levels of activity (direct work as well as national, regional, and global campaigns) and to involve partners in this process. The 'ownership' of any outputs from the partnership and how they will be used should be agreed and made explicit in the partnership agreement. Share risks (especially the risks associated with advocacy work) and share the limelight, making the work and contribution of Oxfam's partners more visible. The advocacy and campaigning toolkits from CPIT are an important support tool. 


\section{Networking and information sharing}

Partners would like more support in making connections - e.g. with other organizations with which Oxfam works, or with others in Oxfam working on similar issues. Partners see Oxfam as a connector: linking them to knowledge, ideas, and networks of organizations across the world. Better sharing of information can be done through simple mechanisms such as sending partners thematic newsletters, training resources, or relevant publications. Partners also want to better understand the structure of Oxfam at country level, particularly the sectoral advisors, and information on country strategies and funding situations, so they can better understand how and why Oxfam makes the decisions it does.

\section{Skills for partnership}

The core skills that help staff to facilitate, coach and problem-solve with partners include listening, observing so as to not to make assumptions, genuinely asking questions in order to learn and behaving with respect towards people. Finding ways to help staff and partners to identify, celebrate, and reinforce these skills among Oxfam staff is critical.

\section{Capacity building}

It may be that Oxfam and partners need time to develop the ability to get the most from the relationship and to deliver results. A capacity building strategy can be agreed at the outset, outlining how much time it will take and what resources will be needed. This can form part of Oxfam's agreements with partners as a fundamental way in which it can be held accountable within a partnership.

\section{Talking about vision and values}

Through the good partnership conversation and on an ongoing basis, it's important to keep communicating about the big ideas as well as the everyday details. This could include discussing theories and models of development (e.g. around government or the private sector), different expectations around partnership styles (especially levels of joint decision making) and differences in professional style (e.g. perceptions of Oxfam's 'bureaucratic' style). It should also include a discussion about who is responsible for the various 'accountabilities' in any relationship: the mutual accountability between Oxfam and a partner and the shared responsibility for accountability to primary and key stakeholders. How will Oxfam's Accountability Minimum Standards be met? Who needs what capacity to make this happen?

\section{Managing risk}

All of Oxfam's work is focused on making change happen - at local, national and/or global levels. As this often involves challenging the status quo and vested interests, most of its work involves some kind of risk. Many project initiatives require complex delivery plans, which might involve risk in terms of whether capacity, systems and procedures are sufficient to ensure the effective management of financial and human resources - often in difficult or complex contexts. Risk doesn't mean not doing things. Oxfam expects all programme staff to manage risk by making a clear assessment of the risk involved, considering with other Oxfam staff and partners the range of strategies needed to manage the risk, and then taking a considered judgement about how to proceed. 


\section{Problem solving and complaints}

Oxfam staff need to communicate clearly its genuine desire to hear 'bad news' about flawed programme design, inappropriate behaviour of staff (of Oxfam or of partners) or external circumstances which could undermine progress toward shared goals. Mechanisms for identifying and addressing such issues should form a part of any agreement Oxfam reaches with its partners and should be communicated to all those concerned. When problems arise from the behaviour of Oxfam staff, it may be difficult for partners to express their concerns for fear of jeopardizing the partnership and the funding. At the outset of a partnership, and prior to starting any new initiative, Oxfam staff should let partners know about the Complaints Policy and how to lodge a valid complaint or register a concern.

\section{Supporting and managing Oxfam's Project Officers}

The work of Oxfam's project officers is critical in establishing good and effective partner relations. The demands on them are many - ranging from clear contract management through to leading participatory organizational assessments, facilitating strategic advocacy planning or mentoring local leaders. Partners have acknowledged that a Project Officer's performance in a partnership is critical to good and effective relations, and they should be performance-managed in such a way as to make them feel that their skill in handling these relationships is both valuable and valued. Think about how to incorporate good partnership practice into their performance objectives.

\section{Multi-pronged partnerships}

Increasingly, Oxfam is working alongside a number of partners from the community, local NGOs, government, and INGOs. These relationships can be used to facilitate policy analysis and the development of advocacy positions and campaigning activities. Working with groups of partners enables Oxfam to take advantage of economies of scale and helps organizations to link up with each other.

\section{Partnership review}

Most partners feel that Oxfam responds well to constructive criticism, but a regular partnership performance review, based on agreements made at the good partnership conversation would be a useful discipline.

\section{Feedback on reports}

Partners would like more feedback on their work. If reports are intended to aid learning and are not just a mechanism for compliance, then a response and ideally some dialogue is essential.

\section{Pay on time!}

Problems in the disbursement of funds are commonly mentioned. A clear schedule of payments and the conditions under which they will be made (e.g. receiving a report on time) should be part of any agreement and should be included in the project milestones in OPAL. If partners are not able to fulfil the conditions for the release of funds, find out what the problem is and how we can help. 


\section{Exit strategies}

There should be clarity in partnership agreements about the circumstances under which a funding relationship may need to end, with an appropriate focus on sustainability and/or good practice exit strategies. This should also be discussed at the good Partnership Conversation. 
For more information, or to comment on this paper, email ywinder@oxfam.org.uk

() Oxfam International June 2016

This publication is copyright but the text may be used free of charge for the purposes of advocacy, campaigning, education, and research, provided that the source is acknowledged in full. The copyright holder requests that all such use be registered with them for impact assessment purposes. For copying in any other circumstances, or for re-use in other publications, or for translation or adaptation, permission must be secured and a fee may be charged. E-mail policyandpractice@oxfam.org.uk.

The information in this publication is correct at the time of going to press.

Published by Oxfam GB for Oxfam International under ISBN 978-0-85598-742-8 in June 2016.

Oxfam GB, Oxfam House, John Smith Drive, Cowley, Oxford, OX4 2JY, UK.

\section{OXFAM}

Oxfam is an international confederation of 20 organizations networked together in more than 90 countries, as part of a global movement for change, to build a future free from the injustice of poverty. Please write to any of the agencies for further information, or visit www.oxfam.org.

Oxfam America (www.oxfamamerica.org)

Oxfam Australia (www.oxfam.org.au)

Oxfam-in-Belgium (www.oxfamsol.be)

Oxfam Canada (www.oxfam.ca)

Oxfam France (www.oxfamfrance.org)

Oxfam Germany (www.oxfam.de)

Oxfam GB (www.oxfam.org.uk)

Oxfam Hong Kong (www.oxfam.org.hk)

IBIS (Denmark) (www.ibis-global.org)

Oxfam India (www.oxfamindia.org)

Oxfam Intermón (Spain) (www.intermonoxfam.org)

Oxfam Ireland (www.oxfamireland.org)

Oxfam Italy (www.oxfamitalia.org)
Oxfam Japan (www.oxfam.jp)

Oxfam Mexico (www.oxfammexico.org)

Oxfam New Zealand (www.oxfam.org.nz)

Oxfam Novib (Netherlands) (www.oxfamnovib.nl)

Oxfam Québec (www.oxfam.qc.ca)

Observers:

Oxfam Brasil (www.oxfam.org.br)

Oxfam South Africa 